International Journal of Child, Youth and Family Studies (2014) 5(2.1): 354-374

Commemorating the Twentieth Anniversary of the Rwandan Genocide.

\title{
THE CHALLENGING ABSENCE OF ADULTS IN YOUTH-HEADED HOUSEHOLDS: THE CASE OF DISSENSION MANAGEMENT AMONG THE FAMILY MEMBERS OF HOUSEHOLDS HEADED BY A SIBLING IN RWANDA
}

\author{
Immaculée Mukashema
}

\begin{abstract}
This exploratory study looks at conflict and dissension occurring in youthheaded households in Rwanda. To gather qualitative data about these issues, seven focus group discussions were conducted with the heads of 41 youth-headed households. Results show that based on a participant's personal experiences, conflict and dissension are common in youth-headed households, manifested in poor communication and the absence of positive interaction between members. The most often reported consequences of this conflict and dissension include household members leaving home and becoming separated from the family, coupled with and exacerbated by health problems and poverty. Participants also reported feeling psychological distress, social isolation, a lack of motivation, and suicidal thoughts. Where there is conflict, participants turn to their own friends or their parents' friends for support. Participants also reported needing economic assistance and psychosocial support. Based on the focus group interviews, the researcher concludes that it would be beneficial to set up specific community-based structures that could deal with all issues of daily life and regulation facing youth-headed households. The researcher recommends that the training of youth-headed households in how to take on family responsibilities should be a national policy.
\end{abstract}

Keywords: conflict, youth-headed households, siblings, Rwanda

Acknowledgements: I am very grateful to the former National University of Rwanda (NUR) in general, to the former NUR's Research Commission and Sida Sarec in particular, for the financing of this research. Many thanks also to Professor Roger Sapsford for his assistance. An early version of this paper was presented to the Third Asian Conference on Psychology and Behavioral Sciences, March 28 to 31, 2013, Osaka, Japan.

Immaculée Mukashema is a Senior Lecturer in Psychology and Mental Health at the Department of Social Sciences, College of Arts and Social Sciences, University of Rwanda, Avenue de l’Université, Butare, B.P. 117 Butare, Rwanda. E-mail: I.MUKASHEMA@ur.ac.rw

Dedication: This research paper is dedicated, first, to the child and youth victims of the genocide against the Tutsi in Rwanda in 1994, second, to the innumerable children and youth who were obliged to assume parental and family responsibilities in its aftermath, and third, to the many more children and youth similarly forced to head families when their parents fell victim to HIV/AIDS in the years since. While none of these children played any part in bringing about these cataclysmic events, they nonetheless suffered the consequences. May the lessons learned 
International Journal of Child, Youth and Family Studies (2014) 5(2.1): 354-374

Commemorating the Twentieth Anniversary of the Rwandan Genocide.

from the tragic experience of my country, Rwanda, translate to greater humanity and respect among all people of all nations, in particular for our children.

In Rwanda, an orphan is defined as a child who has lost either one parent (single-parent orphans) or both parents (double orphans) (Ministry of Gender and Family Promotion [MIGEPROF], 2008, 2011). The Rwandan population was estimated at 10.8 million in 2010/2011. It is a young population, with 54 per cent aged 19 or younger (National Institute of Statistics of Rwanda [NISR], 2012). About 20 per cent of the Rwandan population under the age of 21 are orphans, and among those, $3 \%$ are double orphans, with the highest rate by province (4\%) being in Kigali City (NISR, 2012). According to NISR (2012), the proportion of double orphans in the age range 0 to 20 is 5\% in Kigali City, 2.6\% in the Southern Province, 3\% in the Western Province, 1.6\% in the Northern Province, and 2.5\% in the Eastern Province. Twenty years ago, Rwanda had a large number of orphans without any adult relatives (Boris, Thurman, Snider, Spencer, \& Brown, 2006; UNICEF, 2007) because of the combined effects of the 1994 genocide and the HIV/AIDS epidemic (UNICEF, 2009). Today, the orphans are no longer a consequence of the genocide; HIV/AIDS is the main factor. The number of orphans younger than 15 years of age resulting from HIV/AIDS was estimated to be 203,000 in 2008 (National AIDS Commission [CNLS], 2009). Not only in Rwanda, but also elsewhere in sub-Saharan Africa, the number of double orphans without any relatives is increasing (UNICEF, 2006; Barnet, 2005). Further, existing projections suggest that the number of orphans is likely to continue increasing (UNICEF, 2009).

While on the one hand, the number of orphans in many countries of sub-Saharan Africa, including Rwanda, is increasing, on the other hand there is a move from community-oriented living towards a greater individualization of social organization (see, for example, Hertrich \& Lesclinigand, 2001). In Rwanda this move is occurring despite the country's strong emphasis on community and consensual approaches to problem solving. Indeed, the traditional family and extended family structures suffered a grave blow as a consequence of the genocide against the Tutsi and its aftermath (MIGEPROF, 2011). Traditionally, children and young people were socially involved, and this provided the means for learning practices, manners, and behaviours that the community held as acceptable and "good". As well, children and youth were seen to be well-integrated into the lives of their families (MIGEPROF, 2011; Mukashema \& Sapsford, 2013). With the decline in the traditional systems that included long-standing approaches to fostering orphans, a new phenomenon has emerged whereby young people are heading households as a "family" without parents. These youth-headed households are seen by many as signalling a breakdown in social stability (Roalkvam, 2005). In a youth-headed household, the oldest sibling becomes the head of the household and fulfils the responsibility of caring for the younger siblings (Veale, Quigley, Ndibeshye, \& Nyirimihigo, 2001; Schaal \& Elbert, 2006). In Rwanda, ten years after the genocide against the Tutsi, it was estimated by UNICEF (2004) that 101,000 people were living in 42,000 youth-headed households in Rwanda.

Today, depending on the relationship to the head of household, NISR (2012) suggests that 1.3\% (about 140,400) of the Rwandan population are brothers and sisters living in siblingheaded households. Such youth-headed households are still a relatively new phenomenon about which little is known (Evans, 2010; Uwera \& Brackelaire, 2012). However, it is clear that these 
International Journal of Child, Youth and Family Studies (2014) 5(2.1): 354-374

Commemorating the Twentieth Anniversary of the Rwandan Genocide.

households share some principal characteristics: They form a "family" that provides support and continuity (McAdam-Crisp, 2006); they deal with the adult responsibilities of supporting themselves at an age when the care and the protection of an adult are normally needed (Schaal \& Elbert, 2006); and they assume an anthropological and psychosocial position for which they were never prepared (Boris et al., 2006).

However, it is as yet unclear how these youth-headed households deal with conflict. Since research shows that conflict is a part of family life where adults are generally present - in that conflict occurs between husband and wife, between parent and child (e.g., Canary \& Canary, 2013; Malek, 2010), and between siblings (e.g., Canary \& Canary, 2013; Malek, 2010; Howe, Rinaldi, Jennings, \& Petrakos, 2002; Furman \& Buhmester, 1985) - this begs the question: How do children acting as the head of a family of siblings deal with the inevitable family conflict? Not only are these family units made up of siblings, but they are also siblings living in a new form of alternative family (see Bartoszuk \& Pittman, 2010), caring for younger siblings and fulfilling other adult responsibilities in the absence of adult supervision. Further, when there is conflict between siblings living in traditional families, parents can intervene; but in a youth-headed household the siblings are obliged to live together, as siblings and as "special” family members, in a lifestyle and pattern of authority initiated by their parents but continued in a non-traditional structure that has been arrived at with no choice in the matter. Spouses in traditional families choose freely to get married and live together, while the youth-headed household does not involve choice by all parties. The head of a youth-headed household lacks the moral authority that accompanies public support of the parental role: "you should obey your parent”, but no one says you should obey your brother or your sister.

The research described here investigated conflict and dissension between siblings living in youth-headed households as a new kind of “alternative family” (Bartoszuk \& Pittman, 2010). The research sought to answer the following questions:

- What are the characteristics of the youth-headed households that participated in the present study?

- Do members of such households believe that there is undue conflict and dissension in their youth-headed households?

- What do household members perceive to be the causes of conflict or dissension?

- What are the consequences of these conflicts?

- How do youth-headed household members feel when conflict or dissension occurs?

- What strategies do youth-headed household members use to deal with conflict and dissension? What can be done to help these families headed by young people to achieve a healthy life?

\section{Methods}

\section{Field, population of the study, and selection of participants}

This research was conducted in Huye District, in its four administrative sectors: Ngoma, Mbazi, Gishamvu, and Rwaniro. Huye is one of the Districts of the Southern Province in 
International Journal of Child, Youth and Family Studies (2014) 5(2.1): 354-374

Commemorating the Twentieth Anniversary of the Rwandan Genocide.

Rwanda. In Huye District, the population is estimated at 319,000 and, as in other Districts of Rwanda, that population is young, with 52\% aged 19 or younger (NISR, 2012). In Huye District, $3 \%$ of the population aged 0 to 20 years is composed of double orphans, the national rate being 2.7\% (NISR, 2012).

A qualitative method based on the "basic interpretative research" approach (Merriam, 2002) was selected. This approach is recommended for research when little is known on the topic to be explored (Grenier, 2005), such as the nature of conflict and dissension management among the members of a household headed by a youthful sibling examined in the present research. This approach also allows an overall holistic interpretation that permits the social significance of the data to emerge (Deslauriers \& Mayer, 2000). We gathered our data in focus group discussions because these interactions are known to help to capturing youth experiences more effectively than structured survey research (see, for example, Berg, 1995). Further, over time it has been shown that focus group discussion generates data that are extremely rich and of high quality (Ashar \& Lane, 1991), and that this method has a unique ability to generate data based on the synergy and the stimulation of the group interaction (Hess, 1968; Catterall \& Maclaran, 1997) because group members influence each other by responding to ideas and comments in the discussion (Barnet, 2002; Glitz, 1998; Krueger \& Casey, 2000).

Seven focus group discussions were conducted. These groups were composed of double orphans who were heading households of siblings and who agreed freely and voluntarily to give information about conflict and dissension in their homes. Selection and recruitment of participants was facilitated by the local administration in collaboration with two nongovernmental organizations called, respectively, “Association Modest et Innocent (AMI)” and "Igiti cy’Ubugingo Centre (IUC)”. These two NGOs work with double orphans living in youthheaded households in the four administrative sectors, which were in a rural area. The data collection was carried out between December 2011 and January 2012 at convenient locations in the four administrative sectors.

\section{Research approach}

Two moderators including the principal investigator and two assistants were recruited from among our colleagues on the basis that they had experiences with the community and were therefore comfortable in engaging the youth participants. The moderators underwent two days of training on how to conduct focus group discussions and on the ethics of research with human being as participants. The moderators were provided with a guiding agenda of research questions in Kinyarwanda, the national local language, to use as the tool for the discussions. Keeping in mind the overall research objective of seeking to understand conflict and dissension between siblings living in youth-headed households, the research guide was constructed so that participants could answer open-ended questions pertaining to each to the following themes:

- the participants' beliefs about the existence of undue conflict and dissension in their youth-headed households;

- the perceptions of the participants as household members with respect to the causes of such conflict or dissension;

- the consequences of conflict and dissension on the households;

- the feelings of youth-headed household members when conflict or dissension occurs; 
International Journal of Child, Youth and Family Studies (2014) 5(2.1): 354-374

Commemorating the Twentieth Anniversary of the Rwandan Genocide.

- the strategies used by youth-headed household members to deal with conflict and dissension; and

- recommendations from the participants on what can be done to assist these families achieve a healthy life.

Additionally, in order to generate further information, the moderators asked probing questions during the interview sessions to assist with the clarification of ideas. Each participant signed an informed consent form, and an authorization permitting the recording of the discussion was obtained at the start of each focus group session. With one exception where only female participants were available, separate and parallel sessions were conducted for each gender, to maximize the homogeneity of group members (Brown, 1999) and thus facilitate easy communication. The total number of focus group discussions was seven and included four to seven participants. To promote a relaxed environment during the sessions, participants were given a soft drink as refreshment. At the end of each session participants were financially compensated by receiving 1,500 Rwandan francs (RWFs) or about \$2 U.S. for the day spent travelling to the location of the session and the time spent in the focus group discussion.

\section{Data analysis}

The method of data analysis was based on the approach to content analysis developed by L'Écuyer (1989, 1990). This method shows the essential stages of content analysis by identifying themes and subthemes in what is expressed by participants on a given topic. All seven tapes from the seven focus group discussions were transcribed into seven transcripts, producing a total of 94 pages. These were translated from Kinyarwanda into English. The Kinyarwanda and English versions were then read repeatedly by the principal investigator to "absorb the content" of the discussions (Baribeau, 2009).

The narratives contained in the transcripts were analyzed in order to locate the points of view given by the participants in response to the questions posed in connection with the objective of the study (Duchesne \& Haegel, 2005). The coding was carried out using NVIVO as software for qualitative data coding, which helped in the elaboration of the codes (Duchesne \& Haegel, 2005). Every line, paragraph, and/or section of text was given a specific code. As the coding progressed, the code definitions continued to be challenged and new codes were developed when properties were identified in the data that did not fit the existing codes. During the data analysis, there was constant movement between the raw data and the analysis (see Glaser \& Strauss, 1967; L’Écuyer, 1989; Paillé, 1994; Baribeau, 2009) and constant comparison of categories and codes in each new transcript. The purpose was to fully develop overarching categories for each individual group code. The process was continued until no new code emerged.

\section{Results and Discussion}

Data of this qualitative and exploratory research are presented under the following broad headings relating to the semi-structured interview guide previously described: characteristics of the participants; the existence and signs of conflict and dissension in youth-headed households; 
International Journal of Child, Youth and Family Studies (2014) 5(2.1): 354-374

Commemorating the Twentieth Anniversary of the Rwandan Genocide.

the causes of conflict in youth-headed households; consequences which arise from conflict and dissension; the feelings of the heads of households when conflict and dissension occur; means used by youth-headed households to cope with conflict and dissension; the expressed needs of youth-headed households for coping with conflict; and measures that could be taken to help the youth-headed households mitigate the effects of serious conflict and dissension.

\section{Characteristics and structure of the focus group discussion}

Table 1 summarizes some basic information about the groups. See Column D for the total number of participants. In Column F, the acronym YHH stands for "youth-headed household”.

Table 1. Characteristics and Structure of the Focus Group Discussions (FGDs)

\begin{tabular}{|c|c|c|c|c|c|c|}
\hline A & B & $\mathrm{C}$ & $\mathrm{D}$ & $\mathrm{E}$ & $\mathrm{F}$ & G \\
\hline $\begin{array}{l}\text { Identi- } \\
\text { fying \# } \\
\text { of the } \\
\text { FGD* }\end{array}$ & $\begin{array}{l}\text { Gender } \\
\text { of the } \\
\text { members } \\
\text { of FGD* }\end{array}$ & $\begin{array}{l}\text { Ages and age } \\
\text { range of the } \\
\text { participants in } \\
\text { FGD* }\end{array}$ & $\begin{array}{l}\text { Number } \\
\text { of FGD } \\
\text { members } \\
*\end{array}$ & $\begin{array}{l}\text { Smallest and } \\
\text { largest size of } \\
\text { households } \\
\text { headed by the } \\
\text { participants in } \\
\text { the FGDs* }\end{array}$ & $\begin{array}{l}\text { Period } \\
\text { headed } \\
\text { /lived in } \\
\text { the current } \\
\text { YHHs } \\
\text { (years)* }\end{array}$ & $\begin{array}{l}\text { Range of monthly income } \\
\text { estimations in RWFs } \\
\text { (\$1USD = approx. } 650 \\
\text { RWFs) } \\
<\text { means less than* }\end{array}$ \\
\hline 11 & Male & $\begin{array}{l}\text { 19; } 20 ; 21 ; 24 ; \\
26 ; 17 \\
\text { (range: } 17-26 \text { ) }\end{array}$ & 6 & $2-5$ & $\begin{array}{l}\text { 12; 4; 8; 4; } \\
3 ; 4\end{array}$ & $\begin{array}{l}<10,000 ;<10,000 \\
<10,000 ;<10,000 \\
<10,000 ;<10,000\end{array}$ \\
\hline 21 & Female & $\begin{array}{l}\text { 28; 31; 22; 23; } \\
\text { 17; } 23 ; 21 \\
\text { (range: } 17-31 \text { ) }\end{array}$ & 7 & $2-8$ & $\begin{array}{l}18 ; 17 ; 2 ; \\
2 ; 2 ; 4 ; 5\end{array}$ & $\begin{array}{l}<10,000 ;<10,000 \\
<10,000 ;<10,000 \\
<10,000 ;<10,000 \\
<10,000\end{array}$ \\
\hline 31 & Female & $\begin{array}{l}\text { 24; } 21 ; 21 ; 29 ; \\
\text { 24; one missing } \\
\text { (range: } 21-29 \text { ) }\end{array}$ & 6 & $2-4$ & $2 ; 5 ; 4 ; 4 ; 3$ & $\begin{array}{l}\text { Range 10,000-30,000; } \\
<10,000 ;<10,000 ; \\
<10,000 ;<10,000\end{array}$ \\
\hline 41 & Male & $\begin{array}{l}\text { 17; 20; 21; } 21 \\
\text { (range: 17-21) }\end{array}$ & 4 & $2-3$ & $3 ; 4 ; 1 ; 17$ & $\begin{array}{l}\text { Range 10,000-30,000; } \\
\text { Range 10,000-30,000; } \\
\text { Range 10,000-30,000; } \\
\text { Range 10,000-30,000; }\end{array}$ \\
\hline 51 & Female & $24 ; 20 ; 20 ; 17$ & 6 & $2-5$ & $2 ; 9 ; 9 ; 1 ;$ & $<10,000 ;<10,000$ \\
\hline
\end{tabular}


International Journal of Child, Youth and Family Studies (2014) 5(2.1): 354-374

Commemorating the Twentieth Anniversary of the Rwandan Genocide.

\begin{tabular}{|c|c|c|c|c|c|c|}
\hline & & $\begin{array}{l}23 ; 17 \\
\text { (range: 17-24) }\end{array}$ & & & $6 ; 1$ & $\begin{array}{l}<10,000 ;<10,000 \\
<10,000 ;<10,000\end{array}$ \\
\hline 61 & Female & $\begin{array}{l}\text { 19; 30; 20; 20; } \\
21 ; 18 \\
\text { (range: } 18-30 \text { ) }\end{array}$ & 6 & $2-7$ & $\begin{array}{l}1 ; 17 ; 9 ; 3 ; \\
4 ; 4\end{array}$ & $\begin{array}{l}\text { Range } 10,000-30,000 ; \\
\text { Range } 10,000-30,000 ; \\
<10,000 ;<10,000 ; \\
\text { Range } 10,000-30,000 \text {; } \\
<10,000\end{array}$ \\
\hline 71 & Male & $\begin{array}{l}\text { 25; 28; 24; 22; } \\
22 ; 27 \\
\text { (range: } 22-28 \text { ) }\end{array}$ & 6 & $2-5$ & $\begin{array}{l}\text { 17; 15; 13; } \\
4 ; 17 ; 6\end{array}$ & $\begin{array}{l}<10,000 ;<10,000 \\
<10,000 ;<10,000 \\
<10,000 ;<10,000\end{array}$ \\
\hline & & & Total: 41 & & & \\
\hline
\end{tabular}

*Explanation of the information contained in Table 1:

Column A shows the number identifying the focus groups discussions from 1 to 7 . The first focus group is identified as 11 , the second as 21 , the third as 31 , the fourth as 41 , the fifth as 51 , the sixth as 61, and the seventh focus group is identified as 71 .

Column B pertains to the gender of the participants and shows that focus groups 11,41 , and 71 are composed of male participants, while focus groups 21, 31, 51, and 61 are composed of female participants.

Column $\mathrm{C}$ lists the ages of all the participants in the study and the age range of each of the focus groups. Participants who were 21 years of age at the time of the data collection constitute the largest single age group ( 7 out of a total of 41 participants), followed by participants aged 20 (6 out of 41), and those aged 17 and 24 (each age contributing 5 participants out of 41).

Column D shows that the size of the focus groups varied from 4 to 7 participants.

For each household headed by the participants in focus group discussions, Column E indicates the smallest and the largest number of household members. For example, the smallest size among the households headed by the participants in focus group discussion 11 is 2 people, while the largest household comprises 5 people. Similarly, the smallest number of members among the households headed by the participants in focus group discussion 21 is 2 while the largest is 8. Looking at the sizes of the households headed by the participants in general in Column E, the households ranged from 2 members to a high of 8 members. These household 
International Journal of Child, Youth and Family Studies (2014) 5(2.1): 354-374

Commemorating the Twentieth Anniversary of the Rwandan Genocide.

sizes limits are similar to the general size of households in Rwanda where $84 \%$ of households have between two and seven members (NISR, 2012).

Column F shows respectively the period that the participants have been heading or living in the youth-headed households. The time spent without parents is ranged from 1 to 18 years. The presentation of the ages in Column $\mathrm{C}$ and the duration of time in Column $\mathrm{F}$ are done respectively. This means, for example, that the first participant in focus group 11 is aged 19 years (first in Column C) and has been living in his youth-headed household for 12 years (first in Column F). The next participant in focus group 11, who is aged 20 years (second in Column C), has been living in his youth-headed household during 4 years (same participant as second in Column F).

There are two observations here: Some participants lived in youth-headed households before they actually became the head of the household, for example, when the head left the family in order to marry. For this reason, in the table, some participants have the same age or almost the same age as the time they have spent in the current youth-headed household. One 21year-old participant - the third participant in the Columns $\mathrm{C}$ and $\mathrm{F}$ for focus group 11 - said that he had been living in his youth-headed household for 8 years. Otherwise, this participant should have been heading his household at the age of 21 years minus 8 years, or at 13 years of age, which was not the case. However, there were also many participants who were less than 18 when their parents died and they had started to act as head of households. This accords with previous observations (see, for example, Thurman et al., 2006; Ward \& Eyber, 2009).

Column $\mathrm{G}$ shows the monthly income of each participant as they mentioned it at the time of the data collection. The presentation of the mentioned monthly income is made in the same respective order as in Columns $\mathrm{C}$ and $\mathrm{F}$. Even though there are difficulties with the concept of income in predominantly agricultural countries, and people living on subsistence agriculture may not be good at computing the value of their produce, the majority of participants said they have a household income of less than 10,000 Rwandan francs per month (less than \$15 U.S. per month); this means that participants are extremely poor. The average consumption per poor adult equivalent in real terms in 2011 was RWFs 123,891 at the national level and RWFs 106,754 in the Southern Province (NISR, 2102). At the national level, 44.9\% of the population are identified as poor, and 56.5\% in the Southern Province (NISR, 2012), where Huye District is located. The National Institute of Statistics report (NISR, 2012) doesn't clearly state if the average consumption reported is per year or per month. Still, overall, there is no doubt, based on the data, that the majority of youth-headed household members are very poor.

\section{Existence and signs of conflict and dissension in youth-headed households}

As was expected, conflict and dissension does exist in youth-headed households and tends to manifest in reclusiveness and a lack of positive interaction between members of the household. The experience can be summed up in the following example: 
International Journal of Child, Youth and Family Studies (2014) 5(2.1): 354-374

Commemorating the Twentieth Anniversary of the Rwandan Genocide.

[Y]ou prefer loneliness or directly you go to bed, whereas you should share the meal prepared by your brother who remained at home ...we can spend all the night brawling; they are quarrelling unceasingly, it is always the brawl between them. (11)

\section{Causes of conflict in youth-headed households}

Drinking, the use of drugs, harassing others, youth female family members becoming pregnant, the selfishness of the oldest (and some of the other household members), property and disagreement around the sharing of property (and income): These are said to be the causes of conflict in households headed by young people. Participants expressed the sources of conflict by saying:

As far as I am concerned, I have got an unintended child, I have my little sister and she does not respect me and she always tells me that I have given birth to an illegal child and this always causes conflict. (21)

When these children take or use drugs, they enter into perpetual/everlasting conflict and this may even lead them to kill each other. (41)

Conflict among non-accompanied children may result from the fact that there is no one to teach them to behave, as for most of the time you see them in the same age range. (71) You may live for example with your young brothers and sisters and take care of them, but little by little when you become old enough and mature you become selfish and forget to look after them. (21)

As my friends mentioned, when children live alone, sometimes the eldest becomes impossible and feels that he/she can't get advice from his/her younger brothers/sisters, and thus acts like a dictator towards them. (61)

A major source of conflict reported across groups is a lack of agreement on issues related to property left by the parents, such as such the land, the cows - disagreement on the sharing out of property that was held in common in the youth-headed households. These disagreements were described as follows:

The dissensions can come from the possessions that your parents left you. If you are the elder one of the family, you may be guided by your own interests to the detriment of your brother. You can for example sell a field [land] without informing your brother. When he finds out, he will complain, wanting to know why you did it without him knowing. Thus, conflict may occur between you, because what you do, you do without consulting him, since your heritage is common and shared. (31)

When one of the members gets married, it is also said to be a time of conflict/dissension:

There were some cows at home and my elder brother got married and then he wanted to take them to his household and we refused and this created conflict among us. (71)

Siblings in youth-headed households are victims of poverty and hunger that make it difficult for them to get on well. The households are not able to satisfy the basic needs of their 
International Journal of Child, Youth and Family Studies (2014) 5(2.1): 354-374

Commemorating the Twentieth Anniversary of the Rwandan Genocide.

members and that situation may lead them into conflict and dissension. As the participants noted:

Poverty problems may results in conflict.... It happens that you lack something to eat and conflict may occur from this situation. (21)

In concrete terms, it has been said that conflict often results from poverty, which prevent children in the family from getting on well with each other. Indeed, you can find children who have no parents but live together in harmony because they are never in need. So, you can't realize that they are orphans because they don't come into conflict, thanks to their well-being. (51)

In terms of the sharing of responsibility, youth-headed household members think that it is not only the head (who has to be playing the parental role) who is responsible for getting household needs met; each sibling member of the household who is able to do so needs to make a contribution. As one of the participants said:

For example, if they want to grow beans, they ask the eldest to buy the seed, but he/she has no means; so, when he/she suggests that everybody should contribute, they disagree with him/her and insist that it's up to the eldest to provide the seed. And thus the conflict starts. (51)

In the youth-headed households as well as in other kind of families, the failure to take and fulfil responsibilities is a source of discord and dissension.

\section{Consequences that arise from conflict and dissension in youth-headed households}

Consequences of dissension in youth-headed households, as in other families, may include members leaving home and the breakup of the family. Examples to illustrate these points are related by participants in the following examples:

When there is conflict, a child can flee the family and go in the street to become "a street child". (11)

The first consequence is to leave the family home and to go to wander in the street. (41)

They can leave the house, each going his own way, and live a vagabond life. (61)

When there is conflict or dissension, some sibling members of youth-headed households do not try to deal with it but leave the home. Leaving home may be aimed at searching for better living conditions, but this may end in failure. This failure can be translated, for a girl, in the experience of an unwanted pregnancy:

If it is a girl, she may not go in the street but she may fall unintended pregnant because you do not get along suitably in your family...you may find, for example, some child who fails to live in the family and prefers to live and go to town and when she gets pregnant there she comes back and finds you there without any sufficient means to take care of her. 
International Journal of Child, Youth and Family Studies (2014) 5(2.1): 354-374

Commemorating the Twentieth Anniversary of the Rwandan Genocide.

The consequence of conflict/dissension in youth-headed households may be mental suffering and drug abuse, as in these examples:

You will understand that he/she has a mental disease like trauma, etc. (71)

Now, I have stomach pains. Very recently, I had a stomach attack ...you may feel your heart subjugated by sadness... You may miss the sleep; you may have a generalized malaise, etc. (31)

Drug abuse as a refuge may lead to or itself constitute health problems expressed in mental suffering and in physical illness:

If there are problems in the family, they take refuge in the consumption of drugs and other narcotics. (31)

You may start taking drugs in order to soothe the pain and forget many things you meet in life. (71)

Besides, his/her younger brothers suffer from it enormously. (11)

In situation of conflict and dissension in youth-headed households, if members are not fully capable of work this lead to poverty:

From this situation, the families members cease to work, become poor, and then conflict increase.... Because of living in disagreement and misunderstanding, you do not work, and you become poor. (21)

Another consequence may be extreme poverty because when there is conflict you cannot work in order to develop yourselves.... A severe consequence, as I told you, from my experience, is poverty. (71)

There is the poverty which is due to the misunderstandings in general. (11)

The consequence I find is that they never achieve what they had planned, because of those conflicts. (51)

\section{Feelings of heads of households when conflict and dissension is present in their families}

The heads of household who participated in this research reported a variety of feelings and emotions. These are related to psychological distress, to social isolation from neighbours and from the support of the authorities, to neighbours who made the conflict between siblings worse, to lack of motivation, and to suicidal thoughts and negative sentiments about themselves as heads of household. One example follows:

[It] is the feeling of loneliness and lack of motivation to do something because you do not see any good coming from doing something...lack of people who show they care for you by talking to you, to such an extent that you feeling you are hating all people.... If you have a problem you lack a neighbour who can come and comfort you.... When conflicts occur, frankly speaking, my experience is that no one cares about these orphan children. 
International Journal of Child, Youth and Family Studies (2014) 5(2.1): 354-374

Commemorating the Twentieth Anniversary of the Rwandan Genocide.

Living in conflict and dissension make the heads of households feel stressed, discouraged, and abandoned by a society that does not care about them. Some report feeling like abnormal people. Others remarked on an absence of anyone they could approach for comfort, be it neighbours or authorities. They reported that when they needed to talk to an authority figure, they were afraid to approach that person. They feel abandoned and socially isolated. In turn, because of this feeling of social isolation, they prefer to keep quiet and not tell anyone about their conflict-related problems:

There are moments when one is really in distress, moments when there is nobody who approaches you to comfort you and even the authorities do not come to see you; you never see them...you feel lost. Even when you would need to talk to an authority, you are afraid to approach it...we live in extreme conflict.... I did not understand, I even wanted to commit suicide.... Sometimes, one decides to commit suicide. (31)

Participants reported that in cases of conflict and dissension in their family, the neighbours do not help to solve conflict but instead say things to the elder or younger brother of the head that are intended to worsen the situation and even harm the children's property:

As children living alone, we often face several problems. Neighbours despise us, and harm our property because we don't have any support... With this, neighbours themselves make life difficult for you, because you don't have any friend among them who can take your defence.... Sometimes you find yourself in a bad neighbourhood, but you can't do anything about it. You are aware that you live only thanks to God's will, and not others' will. (61)

This is consistent with the assertion that some neighbours act spitefully toward the young heads of households. Youth-headed households feel a lack of motivation to deal with their responsibilities. They have no motivation to work and may fall into depression, realizing that their previous actions are ineffective:

[T] he consequence is the feeling of loneliness and lack of motivation to do something because you do not see any good coming from doing something...lack of people who care for you by talking to you to such an extent that you feeling you are hating all people. (71)

Sometimes sibling members of youth-headed households living in discordant circumstances have suicidal thoughts. This may be due to conflict, but also may also be linked to situations of social isolation, negative emotionality, and depressive symptoms. Some household members may decide to move far away from their siblings when there is conflict and dissension in their families. The unhealthy situation can lead the heads of youth-headed households to regret being the eldest of the family, as they fear to approach the authorities to speak about their problems: 
International Journal of Child, Youth and Family Studies (2014) 5(2.1): 354-374

Commemorating the Twentieth Anniversary of the Rwandan Genocide.

Most of the time we first lose self-control and regret being the eldest in the family, because of the problems. So, we feel swamped by events but manage to support them, since there is no other solution; sometimes you ask yourself why you are still alive, and you wish you had died. (51)

\section{Means or strategies employed by youth-headed households to face up to family conflict}

In order to cope with conflict and dissension, participants reported sharing their concerns with peers and people of the same age enduring the same experience, their own friends or a parent's friends. Members of youth-headed households reported that they mainly prefer to talk to people with the same experience of conflict and dissension, preferably other young people, their peers, when discussing their experiences and seeking help in finding solutions, rather than having recourse to older people:

[I]nstead of making recourse to the old people, ... better is that young people of your age intervene in your problems (a girl or a boy), contrary to what adults can do.... Another means is to invite another young person of your age to come to intervene in your problems in order to help you to reconcile. (11) It is necessary to seek people who have the same problems as you to talk about it. One exposes his; the other does the same thing. After that, each one feels relieved; each one feels calm and less worried in his heart. (31)

When heads of sibling households encounter family discord, they can go to their own friends or the friends of their dead parents and ask them to intervene with their advice. In conflict and dissension situations, they would be willing to search for help in the extended family - an aunt or uncle - but in general such family members no longer exist:

I run to contact other family members like my aunt because the neighbours do nothing but telling my elder or younger brother things that are intended to worsen the situation.... You try among the family members even though you sometimes lack them. You may lack an aunt or uncle. (71)

\section{Needs in relation to conflict and dissension between siblings in the youth-headed households}

Youth-headed households reported on what they think can be done in order to assist sibling-headed families to no longer live in serious situations of conflict and dissension. They were clear that what they need most of all is economic assistance and psychosocial support:

Financial help for poverty reduction is helpful, because most of the time conflict come from poverty. (21)

I think that there should be organizations which can deal with the studies of these children since they are intelligent. Those who cannot reach secondary studies can profit from vocational training which will help them to fend for themselves in their future like the others. (31) 
International Journal of Child, Youth and Family Studies (2014) 5(2.1): 354-374

Commemorating the Twentieth Anniversary of the Rwandan Genocide.

For my part, I need assistance so that I can get my own home, because I'm about to be chased from where I'm living now.... We need your help because, as the eldest of the family, we are like parents for our young brothers and sisters. When they need something you are unable to find, such as lotion, soap or food, you are overtaken by problems. I think you should help us. (51)

Clearly, the participants in this study need economic assistance to be helped out of poverty.

Youth-headed households need to be approached by counsellors and advisers and they need advocacy. Heads of household said that they needed advice, counselling, advocacy, and adult guidance:

In these problems especially lies the conflict that is found in children-led households...their lack of willingness to solve those problems because these children do not have anyone to advocate for them...frankly speaking, my experience is that no one cares about these orphan children. Orphans, as they lack means, should have people who advocate for them in law, in the courts, because there are many people who have problems in courts and lack advocacy because they do not know the laws and are victimized in front of the law. (71)

Youth-headed households need to be approached regularly and specifically by community leaders, neighbours, and friends. This can help them, especially those who are very young, to overcome the lack of role models, as they put it. It would also help them to deal with the feeling of being marginalized within community structures and give them guidance. As they noted:

Sometimes, children-headed families lack proper education.... Beside this, when one takes drugs, this worsens the situation and makes you live in disagreement or conflict. (41)

Conflict among children without parents may result from the fact that there is no one to help them in how to behave, as for most of the time you are with people in the same age range. You notice that some of them drink beer or take drugs whereas other do not, which is seen as a problem which has the potential to separate them or generate misunderstanding among them. (71)

\section{Actions to be taken}

There is an urgent need for siblings in youth-headed households to be specifically approached in a helpful and supportive way by leaders, counsellors, and advisers. There is also an urgent need for advocacy:

I find that it is good that there is an adviser with whom to exchange ideas; but a mature person, who is capable, not a child as we are, so that we can develop. (11) To have counsellors and advisers for everyday life.... There should be people who can train and advise children-headed families about their everyday life and show them how 
International Journal of Child, Youth and Family Studies (2014) 5(2.1): 354-374

Commemorating the Twentieth Anniversary of the Rwandan Genocide.

they can handle their problems when they occur.... Neighbours, friends, people to be near them and advise them to live in peace. (21)

We also need advocacy. (71)

Youth-headed households also need the community leaders to approach them in order to help them in solving their problems:

Leaders should approach orphans to know their problems in order to solve them properly.... There should be a meeting of children who live together where they discuss their problems. Even one meeting in three months may be sufficient. (21) [T] hey [authorities] should set up a secure place where they can find these children.... One wonders how he will live; when you do not have somebody, an authority to listen to you, to look into your problems, you feel lost. Thus we would like them to approach us where we are, in our villages, our cells, and our sectors...strongly encourage all the basic authorities to take care of the survival of these children, to know how they live from day to day. (31)

They should schedule a day when we can meet and discuss our problems. This is how they can be informed about the problems each child has.... I have never seen any intervention of the authorities when it comes to children to live alone or care for other children. When we are called in general you do not have ways to give your ideas. If you are an authority who cannot take at least one day a year to visit those children, you cannot know their problems. What I am telling you is true.... You cannot know what the child thinks or that there are people who want to harm him in different ways if you don't talk to him. (71)

Mentoring interventions cost little, and have been shown to be effective in a variety of settings (Dubois, Holloway, Valentine, \& Cooper, 2002). Successful mentoring programs may also help to renew social interconnectedness in Rwanda (Boris et al., 2006). Specific structures may need to be put in place to deal with the issues of daily life and regulation confronting youthheaded households. The findings of this study suggest that it is very important to pass laws that specifically recognize the existence of youth-headed households and regulate and support their rights and duties in the same way as the laws that govern other kinds of families. These laws should also deal with the property of such households. In a country that has a high number of youth-headed households (UNICEF, 2009; Lee, 2012) that is likely to increase because traditional foster care is declining, such special measures are clearly necessary. As the older members of these households take over the parental role at an early age and in an unusual way, following the death of their parents, they face challenges that sometimes cause them to regret their seniority in the family. Specific strategies should be put in place to support them in order to preserve their mental health. One such strategy would be to set up a specific and clear structure for their material and psychosocial support.

Because so many member of the youth-headed households that participated in this study stated that they feel a lack of motivation to action, a sense of isolation, and a lack of administrative and social support, this research suggests that it is important to set up a specific national structure to employ strategies dealing with all of the daily life issues experienced in such 
International Journal of Child, Youth and Family Studies (2014) 5(2.1): 354-374

Commemorating the Twentieth Anniversary of the Rwandan Genocide.

households. Included in these policies and approaches should be a special channel of effective advocacy for youth-headed households. Our data shows that there is currently no specific institution that supports youth-headed households; they have nowhere to go where they can find advocacy specific to their needs (see also Clinique Juridique, 2003).

These youth-headed households constitute a new kind of alternative family with a unique structure and social and demographical characteristics that need official recognition and the rights associated with that recognition. These youth-headed households require specific regulations that give them the same rights that are enjoyed by traditional adult-headed households. These rights would enable siblings in youth-headed families to have the same entitlement to socio-economic support - (e.g., the V2020 Umurenge program, one of the strategic programs for fighting poverty in Rwanda) - as adult-headed families, and thus to emerge from the poverty that is one of the causes of conflict and dissension. Further, youthheaded households should be provided with training in family responsibilities, responsibilities like parenting and family management. As one focus group participant explained: Counsellors can also help these children by teaching and training them. The government has a role to play as well...we want people who can come closer to us and advise us (71).

The main aspects - signs, causes, and consequences - of conflict and dissension are present even in traditional families and in other types of alternative families (Malek, 2010; Mukashema \& Sapsford, 2013; Commission Episcopale Justice et Paix Projet, 2007; Slegh \& Kimonoyo, 2010). The youth-headed households in general and those living in conflict and dissension are unique, however, in that no adult member of any other family can say that he or she needs "adult support" to solve family problems. This means that youth-headed households are constantly aware of their vulnerabilities and lack of resources. On the other hand, they have demonstrated their capacity to cope with life events and, through that, their resilience in the face of a most unfavourable situation, that of being orphans without an adult presence in their family lives.

\section{Summary and Conclusion}

This study explored conflict and dissension in youth-headed households using focus group discussion as a method of the data collection. Seven focus groups were conducted with a total of 41 participants. The objectives of the study were to verify the existence of these families and to learn about the signs of conflict and dissension in youth-headed households, its causes, its consequences, the feelings of the heads of these households when conflict and dissension are present, the means used to face it, their needs in relation to such conflict and dissension between siblings, and the expressed needs of youth-headed households so that they can be helped to no longer live with such serious discord.

Conflict does exist in youth-headed households. The most common post-conflict responses of family members are withdrawal and lack of positive interaction between members of the household. Dissension and conflict are most often triggered by behaviours such as drinking, the use of drugs, harassing others, engaging in sexual activity that leads to unintended pregnancy, the perceived selfishness of the oldest (and some other household members), 
International Journal of Child, Youth and Family Studies (2014) 5(2.1): 354-374

Commemorating the Twentieth Anniversary of the Rwandan Genocide.

different views about property and property-sharing, and disagreement around the property (and income) sharing. Additionally, siblings in youth-headed households are often the victims of poverty and hunger that compound the difficulty in getting on well with each other. These young people are unable to satisfy the basic needs of their household members so these privations and conditions of daily life almost inevitably lead to conflict and dissension. The consequences of conflict and dissension in youth-headed households, as in other families, are that family members leave home, endure mental suffering and drug abuse, and that some families break apart. As well, if members are not fully capable of work the family suffers from poverty, underlining and reinforcing the cycle of conflict in the family.

The young people who live youth-headed households and experience conflict and dissension experience psychological distress, social isolation from neighbours and a lack of support from authorities, disengagement from neighbours who often make the conflict between siblings worse, along with a lack of motivation, suicidal thoughts, and negative sentiments about themselves as heads of household. Young heads of households often lack the motivation to deal with their responsibilities. In order to face conflict and dissension, participants reported sharing with peers and people of the same age and the same experience, their own friends or a parent's friends. This study shows that youth-headed households are distressed households whose members need economic assistance and psychosocial support. They require outreach from counsellors and advisers and they need advocacy and guidance. It is therefore recommended that specific structures be put in place to deal with all issues in their daily life and regulation. Judging by this research, it seems of the utmost importance for the Rwandan Government to write legislation that recognizes the existence of youth-headed households and enshrines their rights and responsibilities, in the same way that existing laws govern other kinds of families. 
International Journal of Child, Youth and Family Studies (2014) 5(2.1): 354-374

Commemorating the Twentieth Anniversary of the Rwandan Genocide.

\section{References}

Ashar, H., \& Lane, M. (1991). Focus groups: An effective tool for continuing higher education. Journal of Continuing Higher Education, 41(3), 9-13. http://dx.doi.org/10.1080/07377366.1993.10400881

Baribeau, C. (2009). Analyse des entretiens de groupe [Analysis of group interviews]. Recherches qualitatives, 28(1), 133-148.

Barnet, J. M. (2002). Focus groups tips for beginners. Tcall Occasional Research Paper no.1. Bryan, TX: Texas A\&M University. Retrieved from http://wwwtcall.tamu.edu/orp/orp1.htm.

Barnet, T. (2005). HIV/AIDS, childhood and governance: Sundering the bond of human society. African Journal of AIDS Research, 4(3), 173-182. http://dx.doi.org/10.2989/16085900509490353

Bartoszuk, K., \& Pittman, J. F. (2010). Does family structure matter? A domain specific examination of identity exploration and commitment. Youth and Society, 42(2), 155-173. http://dx.doi.org/10.1177/0044118x10377648

Berg, B. (1995). Qualitative research methods for social sciences (2nd ed.). Boston: Allyn and Bacon.

Boris, N. W., Thurman, T. R., Snider, L., Spencer, E., \& Brown, L. (2006). Infants and young children living in youth-headed households in Rwanda: Implication of emerging data. Infant Mental Health Journal, 27(6), 584-602. http://dx.doi.org/10.1002/imhj.20116

Brown, J. B. (1999). The use of focus groups in clinical research. In B. F. Crabtree \& W. L. Miller (Eds.), Doing qualitative research (2nd ed., pp. 109-124). Thousand Oaks, CA: Sage Publications.

Canary, H. E., \& Canary, D. J. (2013). Family conflict: Managing the unexpected. Cambridge, UK: Polity.

Catterall, M., \& Maclaran, P. (1997). Focus group data and qualitative analysis. Sociological Research Online, 2(1). Retrived from http://www.socresonline.org.uk/2/1/6.html.

Clinique Juridique. (2003). Irengera ry'abana b'Imfubyi mu mategeko mbonezamubano y'u Rwanda /Protection of orphans is civil law of Rwanda. Butare: National University of Rwanda.

Commission Episcopale Justice et Paix Projet. (2007). Renforcement des Structures de la Commission Episcopale de l'Eglise Catholique du Rwanda. Etude de base sur les violences domestiques [Reinforcement of the Episcopale Commission for the Catholic Church of Rwanda. Basic study on domestic violences] (Unpublished Report). 
International Journal of Child, Youth and Family Studies (2014) 5(2.1): 354-374

Commemorating the Twentieth Anniversary of the Rwandan Genocide.

Deslauriers, J. P., \& Mayer, R. (2000). L’observation directe [Direct observation]. In R. Mayer, F. Ouellet, M-R. St-Jacques, D. Turcotte, et al. Méthode de recherche en intervention sociale [Research method in social intervention] (pp. 135-158). Montréal: Gaëtan Morin éd.

Dubois, D. L., Holloway, B. E., Valentine, J. C., \& Cooper, H. (2002). Effectiveness of mentoring programs for youth: A meta-analytic review. American Journal of Community Psychology, 30(2), 157-197.

Duchesne, S., \& Haegel, F. (2005). L'entretien collectif [The collective interview]. Paris: Armand Colin.

Evans, R. (2010). The experiences and priorities of young people who care for their siblings in Tanzania and Uganda (Technical Report). Reading, UK: University of Reading, School of Human and Environmental Sciences, Department of Geography and Environmental Sciences.

Furman, W., \& Buhrmester, D. (1985). Children’s perceptions of the qualities of sibling relationship. Child Development, 56, 448-461. http://dx.doi.org/10.2307/1129733

Grenier, S. (2005). Paradoxe et opportunité de la recherche qualitative en santé mentale communautaire [Paradox and opportunity of qualitative research in community mental health]. Recherches qualitatives- Hors- Série- Numéro 1. Actes de colloques Recherche Qualitative et production des savoirs. UQAM, 12 mai 2004.

Glaser, B. G., \& Strauss, A. L. (1967). The discovery of grounded theory: Strategies for qualitative research. Chicago: Aldine Publishing Company.

Glitz, B. (1998). Focus groups for libraries and librarians. New York: Forbes Custom Publishing.

Hertrich, V., \& Lesclinigand, M. (2001). Transition to adulthood in rural Africa: Are male and female experiences converging? The case of the Bwa of Mali. XXXIV Congrès Général de la population, Salvador, Brazil, August 18-24, 2011. Paris: INRD.

Hess, J. M. (1968). Group interviewing. In R. L. King (Ed.), New science planning (pp. 51-84). Chicago: American Marketing Association.

Howe, N., Rinaldi, C. M., Jennings, M., \& Petrakos, H. (2002). “No! The lambs can stay out because they got cozies": Constructive and destructive sibling conflict, pretend play, and social understanding. Child Development, 73(5), 1460-1473. http://dx.doi.org/10.1111/1467-8624.00483

Krueger, R., \& Casey, M. (2000). Focus groups: A practical guide for applied research (3rd ed.). Newbury Park, CA: Sage. 
International Journal of Child, Youth and Family Studies (2014) 5(2.1): 354-374

Commemorating the Twentieth Anniversary of the Rwandan Genocide.

L’Écuyer, R. (1989). L'analyse développementale du contenu [The developmental analysis of content]. Revu de l'Association pour la Recherche Qualitaitive, 1, 51-80.

L'Écuyer, R. (1990). Méthodologie de l'analyse développementale de contenu: méthode GPS et concept de soi [Methodology of the developmental analysis of content: Method of GPS and self-concept]. Sillery, QC: Presses de l’Université du Québec.

Lee, L. (2012). Strategies to support youth-headed households in Kenya and Rwanda. Backgrounder Number 43. Waterloo, ON: Centre for International Governance Innovation.

Malek, C. (2010). Family conflict. Boulder: University of Colorado.

McAdam-Crisp, J. L. (2006). Factors that enhance and limit resilience for children of war. Childhood, 13(4), 459-477. http://dx.doi.org/10.1177/0907568206068558

Merriam, S. B. (2002). Qualitative research in practice: Examples for discussion and analysis. San Francisco, CA: Jossey-Bass.

Ministry of Gender and Family Promotion. (2008). A situation analysis of orphans and other vulnerable children in Rwanda. Kigali: Government of Rwanda. Retrieved from http://www.dol.gov/ilab/programs/ocft/20090602/rwanda08.pdf .

Ministry of Gender and Family Promotion. (2011). Strategic plan for the integrated child rights policy in Rwanda. Kigali: Government of Rwanda. Retrieved from http://ncc.gov.rw/IMG/pdf/ICRP_Strat_Plan_FINAL_290911.pdf

Mukashema, I., \& Sapsford, R. (2013). Marital conflict in Rwanda: Points of view of Rwandan psycho-socio-medical professionals. Procedia - Social and Behavioral Sciences, 82, (2013), 149-168. http://dx.doi.org/10.1016/j.sbspro.2013.06.239

National AIDS Commission (CNLS). (2009). National strategic plan on HIV and AIDS, 20092012. Kigali: Government of Rwanda.

National Institute of Statistics of Rwanda (NISR). (2012). The third Integrated Household Living Conditions Survey (EICV3): Main indicators report. Kigali: Author.

National Institute of Statistics of Rwanda (NISR). (2012). The third Integrated Household Living Conditions Survey (EICV3): District profile - South - Huye. Kigali: Author.

Paillé, P. (1994). L’analyse par théorisation ancrée [The analysis by anchored theorization]. Cahier de recherche sociologique, 23, 147-181. http://dx.doi.org/10.7202/1002253ar

Roalkvam, S. (2005). The children left to stand alone. African Journal of AIDS Research, 4(3), 2011-2018. http://dx.doi.org/10.2989/16085900509490360 
International Journal of Child, Youth and Family Studies (2014) 5(2.1): 354-374

Commemorating the Twentieth Anniversary of the Rwandan Genocide.

Schaal, S., \& Elbert, T. (2006). Ten years after the genocide: Trauma confrontation and posttraumatic stress in Rwandan adolescents. Journal of Traumatic Stress, 19(1), 95-105. http://dx.doi.org/10.1002/jts.20104

Slegh, H., \& Kimonoyo, A. (2010). Masculinity and gender based violence in Rwanda: Experiences and perceptions of men and women. Kigali: Rwanda Men's Resource Centre.

Thurman, T., Snider, L., Boris, N., Kalisa, E., Mugarira, E., Ntaganira, J., \& Brown, L. (2006). Psychosocial support and marginalization of youth-headed households in Rwanda. AIDS Care: Psychological and Socio-medical Aspects of AIDS/HIV, 18(3), 220-229. http://dx.doi.org/10.1080/09540120500456656

UNICEF. (2004). Rwanda: Ten years after the genocide. Retrieved from http://www.unicef.org/infobycountry/rwanda_genocide.html

UNICEF. (2006). Africa's orphaned and vulnerable generations: Children affected by AIDS. Retrieved from http://www.unicef.org/publications/files/Africas_Orphaned_and_Vulnerable_Generations _Children_Affected_by_AIDS.pdf.

UNICEF. (2007). Une aide pour les orphelins du Rwanda [Help for the orphans of Rwanda]. Retrieved from http://assets.unicef.ch/downloads/fsheet_ruanda_050725_fr_neu.pdf.

UNICEF. (2009). UNICEF Rwanda Background. Retrieved from http://www.unicef.org/infobycountry/rwanda_1717.html.

Uwera, K. C., \& Brackelaire, J. L. (2012). La fratrie dans les ménages d'enfants sans parents au Rwanda après le génocide [Siblingship in households without parents in Rwanda after the genocide]. Dialogue, 2(196), 61-72.

Veale, A., Quigley, P., Ndibeshye, T., \& Nyirimihigo, C. (2001). Struggling to survive: Orphans and community dependent children in Rwanda. Report for Ministry of Local Government and Social Affairs, UNICEF, Trócaire, and Care International. Dublin: Trócaire.

Ward, L. M., \& Eyber, C. (2009). Resilience of children in child-headed household in Rwanda: Implication for community-based psychosocial interventions. Intervention, 7(1), 17-33. http://dx.doi.org/10.1097/wtf.0b013e32832ad3ac 